\title{
ARTYKULY
}

\section{POGLĄDY - SYMPATIE PARTYJNE - WIEDZA POLITYCZNA. PRZEWIDYWANIE ZACHOWAŃ WYBORCZYCH W WYBORACH PARLAMENTARNYCH W 2015 ROKU}

\section{Streszczenie}

Zgodnie z popularną percepcją zachowań wyborczych jednostki głosują na partie, których program i praktyka polityczna zbliżone są do ich światopoglądu. Badania zachowań wyborczych wskazująjednak, że zbieżność programowa ma nieduże znaczenie zarówno dla decyzji wyborczych, jak i samych sympatii i antypatii partyjnych, zwłaszcza w przypadku osób dysponujących niewielką wiedzą polityczną.

W artykule koncentruję się na dwóch kluczowych determinantach zachowań wyborczych: postawach wobec istotnych kwestii politycznych oraz sympatiach i antypatiach partyjnych, analizując zróżnicowanie ich wpływu ze względu na wiedzę polityczną respondentów. W oparciu o dane Polskiego Generalnego Studium Wyborczego 2015 wykazuję, że: 1) ideologiczna przestrzeń rywalizacji w Polsce jest ograniczona, przede wszystkim w zakresie kwestii ekonomicznych, a postawy wobec kwestii politycznych mają ograniczone znaczenie zarówno dla decyzji wyborczych, jak i samych sympatii i antypatii partyjnych; 2) pomimo ograniczonych różnic ideologicznych

\footnotetext{
* Dr, Centrum Studiów nad Demokracja; e-mail: agn.kwiatkowska@swps.edu.pl
} 
podziały polityczne na płaszczyźnie emocjonalnej są silne i są dobrymi predyktorami decyzji wyborczych; 3 ) wiedza polityczna jest czynnikiem silnie moderującym relację między poglądami a sympatiami partyjnymi i zachowaniami wyborczymi; osoby z większą wiedzą polityczną w większym stopniu opierają swoje sympatie i antypatie partyjne na kwestiach programowych.

Słowa kluczowe: zachowania wyborcze, preferencje polityczne, kwestie polityczne, głosowanie tematyczne, wiedza polityczna

\section{WPROWADZENIE}

Zgodnie z popularną percepcją zachowań wyborczych jednostki głosują na partie, których program i praktyka polityczna zbliżone są do ich światopoglądu. Zakłada się, że dzięki zgodności ideologicznej (ideological congruence), rozumianej jako zbieżność poglądów wyborców i przedstawicieli ciał wybieralnych, jednostki są optymalnie reprezentowane, a ich preferencje znajdą urzeczywistnienie w politykach publicznych [Powell 2004]. Zgodnie z formalnym modelem racjonalnego wyborcy istnieje wielowymiarowa przestrzeń rywalizacji partyjnej, w której każdy wyborca ma miejsce wyznaczone przez swoje preferencje polityczne, a pozycje partii określone są na podstawie prezentowanego przez nie programu. Wyborcy głosują na partie położone najbliżej nich w przestrzeni, a w sytuacji, gdy żadna z partii nie jest wystarczająco blisko, nie decydują się na wzięcie udziału w wyborach [Downs 1957; Brody, Page 1972].

Jednak już wczesne badania nad zachowaniami wyborczymi ujawniły niską wiedzę obywateli na temat sfery politycznej i słaby związek pomiędzy postawami wyborców wobec kluczowych kwestii politycznych a zachowaniami wyborczymi. Okazało się, że poglądy w niewielkim stopniu motywują wyborców, bo tylko nieliczna ich grupa jest świadoma głównych problemów spornych w polityce państwa oraz ma wyrobioną opinię na ich temat - odsetek wyborców kierujących się względami ideologicznymi w podejmowaniu decyzji oszacowano na zaledwie $12 \%$ [Campbell, Converse, Miller, Stokes 1960]. W powtórzonym w 2000 roku badaniu wykazano, że odsetek ten wzrósł do $20 \%$ [Lewis-Beck, Jacoby, Norpoth, Weisberg 2008].

Wskazywano również na kluczowy wpływ otoczenia społecznego na partycypację polityczną i zachowania wyborcze, przez co preferencje polityczne stanowią raczej rasowo, klasowo i rodzinnie wykształcone predyspozycje do identyfikowania się z określonymi partiami, niż konsekwencje intelektualnych 
rozważań, i oparte są bardziej na wierze niż na rozumie [Berelson, Lazarsfeld, McPhee 1954]. Dodatkowo, niewielu wyborców posługuje się wysublimowanymi koncepcjami systemu partyjnego, w których partie klasyfikowane są na spektrach ideologicznych pod kątem programu. Poglądy wyborców na poszczególne kwestie są ze sobą niespójne i cechuje je wysoka zmienność w czasie [Converse 1964].

Głosowanie tematyczne - w oparciu o programy partii (issue voting) - wymaga od wyborcy nie tylko świadomości istnienia problematycznych kwestii w debacie publicznej, możliwych ich rozwiązań oraz związku z politykami publicznymi, a także własnych preferencji w tym zakresie, ale również oszacowania względnej „odległości ideologicznej”, w jakiej znajdują się od nich poszczególni kandydaci. Co więcej, notowany historycznie w sondażach wzrost odsetka osób, które można zaklasyfikować jako głosujące tematycznie, nie we wszystkich przypadkach oparty jest na wzroście wiedzy politycznej i zaangażowania wyborców. Dzieje się tak przede wszystkim w przypadku tzw. kwestii łatwych (easy issues), które ze względu na swój symboliczny charakter pozwalają wyborcom na zajęcie stanowiska na podstawie emocji, bez posiadania wiedzy z danego zakresu. W odróżnieniu od nich tzw. kwestie trudne (hard issues) wymagają technicznej wiedzy dotyczącej możliwych rozwiązań politycznych i ich konsekwencji [Carmines, Stimson 1980].

Poza postrzeganą zbieżnością między własnymi poglądami a pozycjami partii politycznych wyborcy kierują się również innego rodzaju informacjami, m.in. postrzeganą zmianą sytuacji ekonomicznej w ostatnich latach, która może stać się podstawą oceny ekipy rządzącej [Fiorina 1981]. Stąd też, nawet pomimo braku szczegółowej wiedzy o programie partii, wyborca jest ją w stanie ocenić na podstawie wyników jej rządów, bardziej zwracając uwagę na efekty polityk niż środki, które do nich doprowadziły. Jednocześnie sympatie polityczne zawierają dodatkowe komponenty przekraczające same poglądy polityczne wyborcy, z których szczególnie istotne są przekonania dotyczące ważności (salience) kwestii, a także powiązanie przez opinię publiczną poszczególnych kwestii z konkretnymi partiami (issue ownership) oraz przekonania dotyczace kompetencji partii (party competence) w radzeniu sobie z tymi problemami [van der Brug 2017]. Szczegółowe i obszerne zestawienie rezultatów kluczowych badań politologicznych w zakresie głosowania tematycznego przedstawione zostały m.in. w pracach zbiorowych pod redakcją Daltona i Klingemanna [2010] i Fishera et al. [2010].

Z drugiej strony, niska wiedza polityczna wyborców czyni ich bardziej skłonnymi do oceniania wedle kryteriów pozamerytorycznych i utrudnia im możliwość osobistej weryfikacji komunikatów marketingowych kandydatów. 
Wiedza polityczna, zdefiniowana jako „zasób informacji o polityce, który jest potrzebny jednostce do bycia dobrym obywatelem demokratycznego państwa" [Raciborski 2011, 206], pozwala jednostkom na aktywne i skuteczne działanie zgodnie $\mathrm{z}$ własnymi preferencjami i interesami w ramach instytucjonalnego systemu politycznego. Ta możliwość przekłada się na wyższe poczucie sprawstwa politycznego, wzrost uczestnictwa wyborczego oraz wyższą satysfakcję z demokracji i przywiązanie do demokratycznych wartości [por. Żerkowska-Balas, Cześnik, Zaremba 2017].

Uwzględniając wielość modeli teoretycznych zachowań wyborczych, Polskie Generalne Studium Wyborcze - podobnie jak wiele innych studiów wyborczych na świecie - wykorzystuje szereg determinantów decyzji wyborczych, umożliwiając jednoczesne testowanie ich wpływu. Ze względu na ograniczoną objętość artykułu koncentruję się na dwóch kluczowych determinantach zachowań wyborczych - poglądach politycznych oraz sympatiach i antypatiach partyjnych [por. Bartkowski, Cześnik, Kotnarowski 2011], oraz zróżnicowaniu ich wpływu ze względu na wiedzę polityczną respondentów, pomijając m.in. kwestię postrzeganej zbieżności (proximity) pozycji między wyborcami a partiami [Markowski, Tucker 2017], identyfikacji partyjnej oraz głosowania retrospektywnego [Markowski, Cześnik, Kotnarowski 2011].

W oparciu o badania PGSW 2015 wykazuję, że: 1) ideologiczna przestrzeń rywalizacji w Polsce jest ograniczona, przede wszystkim w zakresie kwestii ekonomicznych (preferencje wobec systemu podatkowego, zakresu świadczeń socjalnych); 2) z powodu zbliżonej pozycji większości ugrupowań postawy wobec kwestii politycznych mają ograniczone znaczenie zarówno dla decyzji wyborczych, jak i samych sympatii i antypatii partyjnych; spośród badanych siedmiu kwestii najsilniejszy wpływ na zachowania wyborcze i sympatie partyjne wywierają postawy wobec Unii Europejskiej, a także wobec obecności Kościoła w polityce i dopuszczalności aborcji; 3) wpływ poglądów na ocenę partii i zachowania wyborcze jest zróżnicowany między elektoratami: najmniej wyróżniające się ideologicznie są elektoraty PSL i Kukiz'15, najbardziej - Nowoczesnej i KORWiN; 4) pomimo powszechnej niechęci wobec partii większość Polaków posiada partię, którą ocenia lepiej niż pozostałe, jednak znacznie więcej osób jest w stanie wymienić partię, do której czuje prawdziwą niechęć niż taką, wobec której wprost zadeklaruje, że jest im bliższa niż inne; 5) pomimo ograniczonych różnic ideologicznych podziały polityczne na płaszczyźnie emocjonalnej są silne i są dobrymi predyktorami decyzji wyborczych, przede wszystkim w przypadku elektoratów PiS i KORWiN, a w najmniejszym stopniu w przypadku wyborców 
PSL i Kukiz'15; 6) wiedza polityczna jest czynnikiem silnie moderującym relację między poglądami a sympatiami partyjnymi i zachowaniami wyborczymi; osoby z większą wiedzą polityczną w większym stopniu opierają swoje sympatie $i$ antypatie partyjne na kwestiach programowych ${ }^{1}$.

\section{OGRANICZONA PRZESTRZEŃ RYWALIZACJI}

Pomimo panującego - przede wszystkim w przekazie medialnym - wszechogarniającego konfliktu na polskiej scenie politycznej, gdy przyjrzymy się szczegółowo poglądom na szereg kwestii politycznych, różnice ideologiczne między zwolennikami głównych partii okazują się znacznie mniejsze, a w niektórych przypadkach nieistotne. Wybór, przed jakim stają obywatele w wyborach, jest więc mocno ograniczony. Tymczasem, zdaniem Dahla [1995], istnienie konkurujących ze sobą opcji politycznych jest warunkiem koniecznym nowoczesnej demokracji. System partyjny powinien strukturyzować rywalizację polityczna, dostarczając obywatelom szeroki wybór pozycji ideologicznych, powiązanych ze spójnymi pakietami polityk publicznych proponowanych w programach partyjnych [Dunleavy, Taylor 2017: 46].

Elektoraty głównych partii dzielą przede wszystkim kwestie światopoglądowe: w badaniu PGSW 2015 pytania z tego obszaru objęły stosunek do legalizacji przerywania ciąży oraz do relacji państwo-Kościół. Coraz silniejszą moc dyskryminacyjną mają również kwestie związane z wymiarem międzynarodowym: z pogłębianiem współpracy w ramach Unii Europejskiej oraz ze stosunkiem do osiedlania się cudzoziemców w Polsce 2 . Z kolei w przypadku kwestii ekonomicznych różnice między partiami są znacznie mniejsze, a jedyną partią o wyraźnie odmiennym od większości, liberalnym stanowisku jest KORWiN i, w mniejszym stopniu, Nowoczesna.

1 Praca powstała w ramach realizacji projektu badawczego o $\mathrm{nr}$ 2017/01/X/HS5/00708 finansowanego ze środków Narodowego Centrum Nauki.

2 Podobne kwestie do obserwowanych w elektoratach zidentyfikowane zostały jako dzielące partie również na poziomie głosowań parlamentarnych [Kwiatkowska 2018]. 


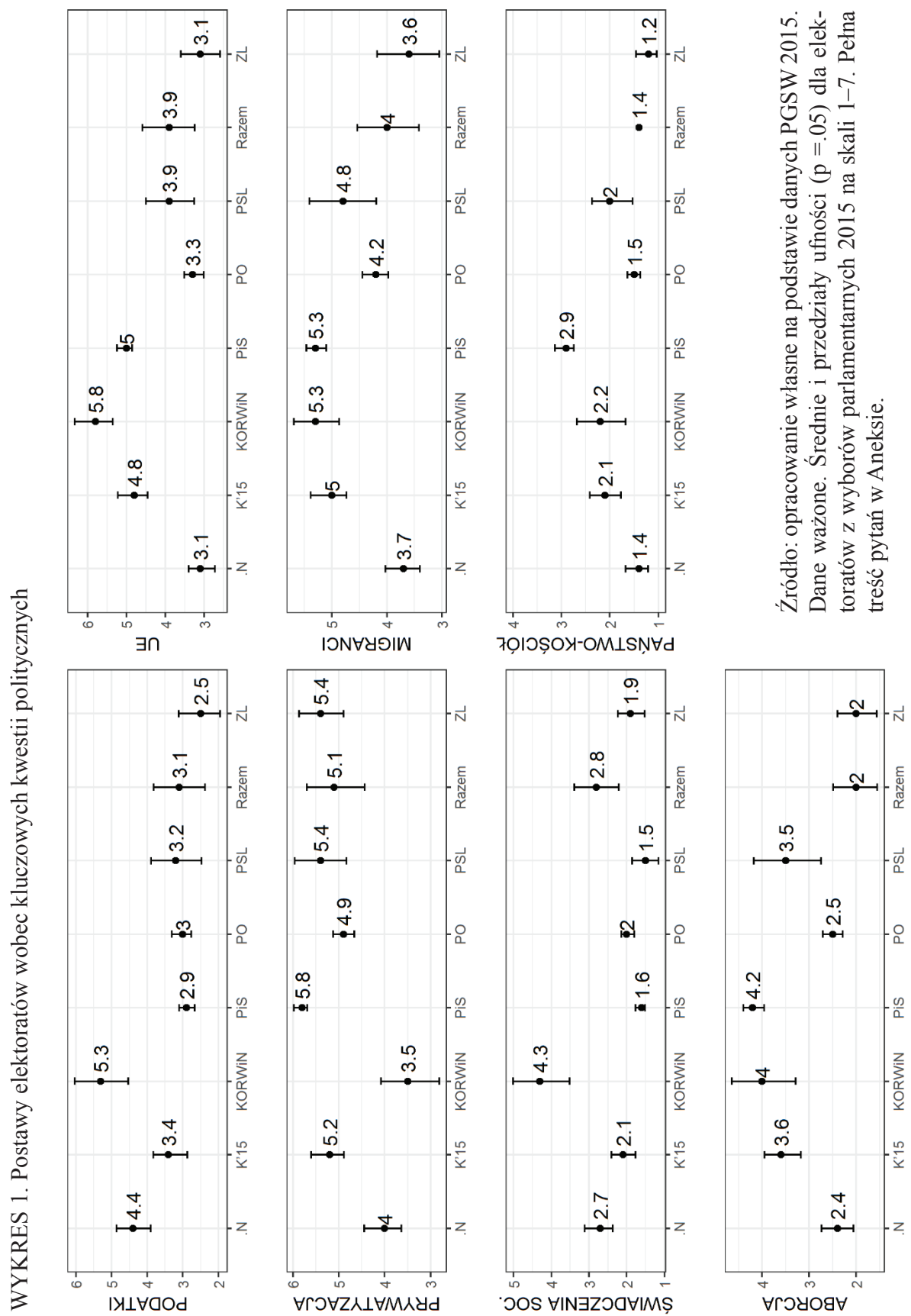


Najmniejsze różnice między elektoratami zachodzą w przypadku preferencji wobec systemu podatkowego (średnia dla ogółu respondentów 3,19 na skali 1-7): zwolennicy niemal wszystkich ugrupowań opowiadają się w umiarkowany sposób za podatkiem progresywnym, a pomiędzy większością partii (PO, PiS, PSL, ZL, Kukiz'15, Razem) nie zachodzą istotne statystycznie różnice. Zwolennicy wersji liniowej systemu podatkowego to wyjątki: przede wszystkim KORWiN (różniący się istotnie w tej kwestii od wszystkich partii, poza Nowoczesną) i Nowoczesna (różnice w stosunku do: PiS, PO i ZL).

Pozostałe badane kwestie ekonomiczne również nie stanowią podłoża silnych konfliktów ideologicznych pomiędzy głównymi partiami. Polacy w zdecydowanej większości uważają że państwo powinno zapewniać obywatelom możliwie pełny zakres świadczeń społecznych, takich jak ochrona zdrowia, pomoc społeczna, edukacja (średnia 1,9). Liberalnymi ekonomicznie wyjątkami są, podobnie, KORWiN (tylko temu ugrupowaniu bliżej jest do drugiego końca skali, zgodnie z którym obywatele sami powinni dbać o zapewnienie sobie ochrony zdrowia, samopomoc, kształcenie dzieci itp.) i, w dalszej kolejności, Nowoczesna, która jest bardziej liberalna od wszystkich partii parlamentarnych poza blokiem Kukiz'15. Różnica średnich między PO i PiS chociaż istotna statystycznie, jednak jest niewielka $(0,34, \mathrm{p}<0,05)$.

W zbliżony sposób wygląda ułożenie partii pod kątem stosunku do prywatyzacji. Zdecydowana większość ugrupowań podziela stanowisko, zgodnie z którym znaczna liczba przedsiębiorstw powinna pozostać własnością państwową, co odpowiada również poglądom ogółu obywateli, dla których średnia wynosi 5,3. Alternatywny pogląd - że należy sprywatyzować wszystkie przedsiębiorstwa państwowe - prezentuje KORWiN; Nowoczesna sytuuje się pomiędzy tymi stanowiskami. Problem prywatyzacji pozostaje kwestią ekonomiczną najsilniej dzielącą elektoraty dwóch największych partii: PO i PiS.

W kwestiach ekonomicznych panuje zatem między elektoratami dość duża zbieżność poglądów. Wyróżniającymi się ugrupowaniami sąjedynie Nowoczesna i pozaparlamentarny KORWiN. Reszta partii podziela zbliżone, prosocjalne stanowisko, a różnice między nimi są niewielkie bądź, w większości przypadków, statystycznie nieistotne. Tym, co znacznie silniej dzieli elektoraty, są natomiast kwestie światopoglądowe.

Niezależnie od powszechnej religijności Polacy opowiadają się na ogół za oddzieleniem Kościoła od państwa i ograniczeniem jego wpływu na politykę (średnia 2,04, na skali 1-7). Największe przyzwolenie na wywieranie przez Kościół wpływu na politykę państwową występuje wśród wyborców PiS. Elektorat PiS różni się w sposób istotny statystycznie od wszystkich partii poza KORWiN 
(który - ze względu na dużą rozbieżność poglądów zwolenników - różni się tylko od ZL z drugiego krańca skali). Stosunkowo mało na tle pozostałych partii na rozdział między państwem i Kościołem naciskają zwolennicy Kukiz'15 - istotne różnice występują w stosunku do wszystkich partii poza PiS i PSL. Różnice między pozostałymi partiami, opowiadającymi się za separacją państwo-Kościół: PO, ZL, .N, PSL - nie są istotne statystycznie.

Poglądy Polaków na kwestię dopuszczalności przerywania ciąży są zróżnicowane, jednak średnia na poziomie ogółu społeczeństwa pomiędzy skrajnymi punktami skali: „Kobieta - jeśli tak zadecyduje - powinna mieć prawo do aborcji w każdej sytuacji” z jednej strony, i „Kobieta - niezależnie od swej sytuacji społecznej czy zdrowotnej - nie powinna mieć prawa do aborcji" z drugiej, wypada nieco bliżej liberalnego końca $(3,2)$. Wśród elektoratów najbardziej liberalne stanowisko zajmują: Zjednoczona Lewica i Razem, a w dalszej kolejności Nowoczesna i PO. Na konserwatywnym biegunie znajdują się natomiast PiS, KORWiN i Kukiz'15. Słabo sprecyzowane stanowisko wyborców PSL lokuje ich pomiędzy tymi dwoma blokami (różnią się w sposób istotny statystycznie wyłącznie od Razem i ZL).

W ostatnich latach obserwujemy wzrost mocy dyskryminacyjnej kwestii związanych z trzecim wymiarem rywalizacji politycznej w Polsce - polityką wobec Unii Europejskiej i stosunkiem do migrantów [Kwiatkowska, Cześnik, Żerkowska-Balas, Stanley 2016]. Blok opowiadający się za ścisłą współpracą w polityce zagranicznej z Unią Europejską i podporządkowaniem się regułom w niej obowiązującym, reprezentują elektoraty Nowoczesnej, ZL, PO, a w mniejszym stopniu (przez co nie różnią się w istotny sposób od bloku eurosceptycznego) PSL i Razem. Z drugiej strony podziału, opowiadając się za twierdzeniem, że polska polityka zagraniczna powinna przede wszystkim bronić politycznej i gospodarczej niezależności kraju, nawet za cenę wystapienia z Unii Europejskiej, znajdują się wyborcy KORWiN, PiS i Kukiz'15. Średnia opinii na poziomie ogółu społeczeństwa zbliżona jest do środkowego punktu skali (4,3).

Kryzys uchodźczy w Unii Europejskiej, pomimo nikłego odsetka obcokrajowców w Polsce, zaostrzył niechęć wobec imigrantów (średnia ogółu społeczeństwa to 4,8) i nasilił znaczenie tej kwestii w rywalizacji politycznej. Podział na zwolenników tezy, że władze powinny zachęcać do osiedlania się w Polsce obywateli innych państw, którzy mają na to ochotę (ZL, .N, Razem, w mniejszym stopniu PO) versus twierdzenia, że władze powinny przeciwdziałać osiedlaniu się w Polsce cudzoziemców (PiS, KORWiN, K'15), jest podobny jak w przypadku kwestii integracji europejskiej (również z wyborcami PSL umiejscowionymi pomiędzy blokami), jednak różnice między blokami są znacznie mniejsze. 
Podsumowując, różnice ideologiczne pomiędzy elektoratami poszczególnych partii są ograniczone, zwłaszcza jeśli zawęzimy analizę do partii posiadających reprezentację parlamentarną. Dodatkowo, różnice dotyczą przede wszystkim kwestii łatwych: o charakterze symbolicznym, odnoszących się do tożsamości i spójności grupowej, niewymagających uzgodnienia i zrozumienia szczegółów technicznych.

Tylko nieliczne kwestie w sposób istotny pozwalają na rozróżnienie między sobą zwolenników poszczególnych ugrupowań, natomiast łączne uwzględnienie ich w modelu (z niegłosującymi jako kategorią referencyjną) pozwala na stworzenie profili ideologicznych elektoratów. Wśród zamieszczonych w tabeli 1 ideologicznych determinant decyzji wyborczych, a więc wpływu siedmiu opisanych powyżej kwestii na głosowanie w wyborach parlamentarnych w 2015 roku, znaczenie ma przede wszystkim stosunek do integracji europejskiej - jest on istotną kwestią dla wszystkich elektoratów poza PSL i Kukiz'15, przy czym wyborców PO, ZL i .N charakteryzuje nacisk na pogłębianie współpracy w ramach Unii, a wyborców PiS i KORWiN - eurosceptycyzm. Te trzy proeuropejskie elektoraty (PO, ZL, .N) charakteryzuje również bardziej pozytywny stosunek do osiedlania się w Polsce cudzoziemców w porównaniu do większości obywateli. W dalszej kolejności kwestią istotną dla elektoratów poszczególnych partii jest dopuszczalność przerywania ciąży, która, ponownie, rozdziela bardziej liberalne światopoglądowo elektoraty ZL i PO (w przypadku Nowoczesnej wynik nie jest istotny statystycznie) od wyborców KORWiN i PiS popierających restrykcyjną politykę wobec aborcji.

Spośród kwestii ekonomicznych największą moc dyskryminacyjną mają stosunek do prywatyzacji oraz do świadczeń socjalnych. W pierwszym przypadku spośród socjalnej większości ugrupowań wyróżniają się, z bardziej liberalnym stanowiskiem, KORWiN, .N i PO; w drugim - liberalnymi wyjątkami są KORWiN, .N i Kukiz'15. Mniejsze znaczenie w zakresie kwestii ekonomicznych mają preferencje wobec typu systemu podatkowego: większość wyborców popiera podatek progresywny (zwłaszcza wyborcy PiS); jako zwolennicy podatku liniowego wyróżniają się w sposób istotny statystycznie wyborcy Nowoczesnej.

Warto również zwrócić uwagę na to, że o ile dla większości elektoratów istotne są przynajmniej cztery kwestie, o tyle nie znajdujemy żadnej płaszczyzny, która wyróżniałaby wyborców PSL - mają oni we wszystkich sprawach podobne zdanie jak większość wyborców i wyrażają je w umiarkowanym zakresie. Niewiele więcej, bo tylko kwestia świadczeń socjalnych, wyróżnia jako elektorat wyborców Kukiz'15. Świadczy to o braku wyrazistej formy ideologicznej tych ugrupowań. Dodatkowo, przesunięcie większości elektoratów w kierunku socjalnym sprawia, 
że ZL, będące jedynym ugrupowaniem lewicowym w tym gronie, nie wyróżnia się na ich tle w zakresie kwestii ekonomicznych.

TABELA 1. Wpływ poglądów politycznych na decyzje wyborcze

\begin{tabular}{|c|c|c|c|c|c|c|c|c|}
\hline \multirow{3}{*}{$\begin{array}{c}\text { Stosunek } \\
\text { do kwestii: }\end{array}$} & \multicolumn{7}{|c|}{ Głosowanie w wyborach parlamentarnych $2015 \mathrm{r}$. } & \multirow{3}{*}{$\begin{array}{c}\begin{array}{c}\text { LR chi }{ }^{2} \\
\text { (Sig.) }\end{array} \\
\text { Pelny } \\
\text { model: } \\
581,9^{* * *}\end{array}$} \\
\hline & PiS & $\mathrm{PO}$ & PSL & ZL & K'15 &. $\mathrm{N}$ & KORWiN & \\
\hline & $\operatorname{Exp}(B)$ & $\operatorname{Exp}(B)$ & $\operatorname{Exp}(B)$ & $\operatorname{Exp}(B)$ & $\operatorname{Exp}(B)$ & $\operatorname{Exp}(B)$ & $\operatorname{Exp}(B)$ & \\
\hline $\begin{array}{l}\text { państwo- } \\
\text {-Kościół }\end{array}$ & $1,31 * * *$ & 0,92 & 1,06 & 0,76 & 1,02 & 0,86 & 0,93 & $60,1 * * *$ \\
\hline podatki & $0,92 * *$ & 0,98 & 1,02 & 0,92 & 0,99 & $1,19 * *$ & 1,18 & $28,5^{* * *}$ \\
\hline $\begin{array}{l}\text { Unia } \\
\text { Europejska }\end{array}$ & $1,11 * *$ & $0,79 * * *$ & 0,86 & $0,81 * *$ & 1,12 & $0,76^{* * *}$ & $1,43 * *$ & $85,0^{* * *}$ \\
\hline migranci & 1,04 & $0,87 * *$ & 0,96 & $0,75^{* * *}$ & 1,02 & $0,79 * *$ & 1,12 & $32,1 * * *$ \\
\hline $\begin{array}{l}\text { świadczenia } \\
\text { socjalne }\end{array}$ & 0,95 & 1,10 & 0,84 & 1,05 & $1,18^{*}$ & $1,35^{* * *}$ & $1,62^{* * *}$ & $49,8 * * *$ \\
\hline prywatyzacja & 1,09 & $0,88 * *$ & 0,96 & 1,05 & 0,92 & $0,78^{* * *}$ & $0,66^{* * *}$ & $44,9 * * *$ \\
\hline aborcja & $1,17 * * *$ & $0,91 *$ & 1,13 & $0,77^{*}$ & 1,09 & 0,88 & $1,25^{*}$ & $49,1 * * *$ \\
\hline $\begin{array}{l}\text { \% poprawnych } \\
\text { przewidywań }\end{array}$ & $41,8 \%$ & $18,6 \%$ & $0,0 \%$ & $0,0 \%$ & $0,0 \%$ & $17,2 \%$ & $41,4 \%$ & \\
\hline
\end{tabular}

Źródło: opracowanie własne na podstawie danych PGSW 2015. Dane ważone. $\mathrm{N}=1424$. Regresja wielomianowa logistyczna: podane ilorazy szans $(\operatorname{Exp}(B))$ i istotność statystyczna $(* p<0.05$, ** $\mathrm{p}<0,01, * * * \mathrm{p}<0,001)$. Niegłosujący jako grupa referencyjna. Ze względu na dużą liczbę braków danych model nie obejmuje partii Razem. Odsetek poprawnych przewidywań (uwzględniając niegłosujących): 46,1\%, Nagelkerke Pseudo $\mathrm{R}^{2}=0,349$.

\section{SYMPATIE PARTYJNE I ZACHOWANIA WYBORCZE}

Chociaż poparcie dla demokracji jako systemu rządów w porównaniu z systemami autorytarnymi jest w Polsce wysokie, to cały region postkomunistycznej Europy Środkowo-Wschodniej stanowi obszar relatywnie niskiego poparcia dla demokracji na poziomie światowym [van der Meer 2017]. Obywatele polscy wykazują skrajnie niski poziom akceptacji dla głównych aktorów tego systemu politycznego - partii politycznych. Zgodnie z danymi CBOS na przestrzeni lat zaufanie do partii nigdy nie przekroczyło $20 \%$, wliczając w to osoby, które „zdecydowanie” lub „raczej” ufają partiom. Dodatkowo, zdaniem ponad 80\% Polaków partie polityczne robią więcej złego niż dobrego, a tylko $2 / 5$ uznałoby, że gdyby z jakichś powodów wszystkie partie polityczne musiały zaprzestać swej działalności, to byłoby to ze szkodą dla Polski [CBOS 2011]. 
Zgodnie z danymi PGSW 2015 69,8\% badanych twierdzi, że partie przedstawiły w wyborach zróżnicowaną ofertę programową a 60,6\% czuje się dobrze reprezentowane przez przynajmniej jedną partię. Jednak znacznie mniej, bo $40,8 \%$ badanych, posiada partię, która w ich odczuciu jest im bliższa niż inne ugrupowania. Przede wszystkim dotyczy to ugrupowań dużych - Prawa i Sprawiedliwości - 42,7\% spośród identyfikujących się z jakąś partią, i Platformy Obywatelskiej - 25,6\% (można było wskazać więcej niż jedną partię, jednak decydowały się na to tylko pojedyncze osoby). To poczucie bliskości na ogół nie jest zbyt silne - tylko $8,1 \%$ osób spośród tych, które wskazały, że jakaś partia jest im bliższa niż inne, określiły, że czują się „bardzo mocno” z nią związane. Pozostali czują tę więź jako „raczej mocną” (47,1\%) lub „niezbyt mocną” (42,9\%) bądź mają problemy z określeniem jej charakteru $(1,9 \%)$.

Natomiast jeszcze więcej Polaków ma partię, której nie lubi. Ponad połowa (50,9\%) badanych wskazało co najmniej jedną partię, do której czuje „prawdziwą niechęć, złość". Ponownie najczęściej wskazywane są największe i najbardziej rozpoznawalne ugrupowania - w gronie osób, które posiadają nielubianą partię, najczęściej wskazywany jest PiS $(55,1 \%)$, PO (31,1\%) oraz KORWiN $(13,3 \%)$. $\mathrm{Z}$ punktu widzenia demokracji liberalnej najbardziej istotny jest natomiast fakt, że spośród tych osób prawie trzecia część (dokładnie 31,3\%) uważa, że powinno się prawnie zakazać funkcjonowania partii, której nie lubia, podczas gdy $58,6 \%$ pozwoliłoby jej dalej funkcjonować, a pozostali nie mają w tej kwestii wyrobionego zdania. Najczęściej delegalizacji nielubianej partii życzy sobie elektorat Prawa i Sprawiedliwości (34\%), KORWiN (32\%), a także wyborcy PO (32\%) i PSL (31\%). Z kolei największą tolerancją i poszanowaniem konkurentów charakteryzują się elektoraty Razem (13\%) i Nowoczesnej (22\%). Natomiast partiami najczęściej typowanymi do zdelegalizowania są: KORWiN (opowiada się za tym 37,9\% osób, które zadeklarowały, że nie lubią tej partii), a w dalszej kolejności - osoby, w których niechęć budzą: Platforma Obywatelska, Razem oraz Prawo i Sprawiedliwość (odpowiednio: 35,8\%, 33,3\% i 31,3\%).

Współczesne partie nie podobają się Polakom bez wyjątku: w pytaniu o stosunek emocjonalny wobec poszczególnych partii nie było ani jednej, która oceniona zostałaby przeciętnie na poziomie wyższym niż środkowy punkt skali. Najmniej podobają się Polakom ugrupowania: KORWiN (średnia 1,75 na skali $0-10$ ), SLD/ZL $(2,48)$ i Razem $(2,66)$. Najbardziej lubiane - a precyzyjniej, najmniej nielubiane - są PiS $(4,41)$, Nowoczesna $(3,62)$ i PO $(3,4)$. Ze względu na to, że silnie wpływającym na te wyniki czynnikiem jest wielkość elektoratów (duża liczba wyborców partii zwiększa średnią), w tabeli 2 podane zostały również wartości 
średnich partii z wyłączeniem ocen osób, które na nie zagłosowały w wyborach parlamentarnych w 2015 roku. Po wykluczeniu własnych elektoratów najbardziej lubianymi partiami okazują się Nowoczesna $(3,61)$, PiS $(3,19)$ i Kukiz'15 $(3,1)$.

TABELA 2. Ocena partii politycznych przez elektoraty

\begin{tabular}{|c|c|c|c|c|c|c|c|c|c|}
\hline \multirow{2}{*}{$\begin{array}{c}\text { Głosowanie } \\
\text { w wyborach } \\
\text { parlamentar- } \\
\text { nych } 2015\end{array}$} & \multicolumn{8}{|c|}{ Średnia ocena poszczególnych partii } & \multirow{2}{*}{$\begin{array}{c}\text { Średnia } \\
\text { (bez } \\
\text { własnej } \\
\text { partii) }\end{array}$} \\
\hline & PiS & PO & PSL & $\mathrm{ZL}$ & Kukiz'15 &. $\mathrm{N}$ & KORWiN & Razem & \\
\hline $\begin{array}{l}\text { Nie } \\
\text { głosował }\end{array}$ & 4,01 & 3,23 & 3,03 & 2,65 & 3,39 & 3,05 & 1,92 & 2,58 & 2,98 \\
\hline PiS & 7,69 & 2,18 & 2,42 & 1,75 & 3,82 & 2,43 & 1,65 & 1,8 & 2,29 \\
\hline $\mathrm{PO}$ & 1,88 & 6,23 & 3,63 & 3,06 & 1,81 & 4,52 & 0,75 & 2,9 & 2,65 \\
\hline PSL & 3,11 & 3,23 & 5,81 & 2,45 & 2,55 & 3,44 & 0,99 & 2,05 & 2,55 \\
\hline ZL & 1,58 & 3,3 & 2,99 & 6,07 & 1,83 & 4,69 & 0,61 & 3,65 & 2,66 \\
\hline Kukiz'15 & 4,14 & 2,18 & 2,31 & 1,57 & 7,58 & 3,36 & 2,64 & 2,85 & 2,72 \\
\hline. $\mathrm{N}$ & 1,49 & 4,2 & 2,75 & 2,5 & 1,89 & 7,49 & 1,49 & 3,2 & 2,5 \\
\hline KORWiN & 3,74 & 1,4 & 1,35 & 1,05 & 5,59 & 2,69 & 8,12 & 1,79 & 2,52 \\
\hline Razem & 2,36 & 3,69 & 2,72 & 2,98 & 2,48 & 4,63 & 1,16 & 6,92 & 2,86 \\
\hline $\begin{array}{l}\text { Średnia } \\
\text { (bez własnej } \\
\text { partii) }\end{array}$ & 3,19 & 2,87 & 2,85 & 2,36 & 3,1 & 3,31 & 1,57 & 2,52 & \\
\hline Średnia & 4,41 & 3,4 & 2,94 & 2,49 & 3,4 & 3,61 & 1,75 & 2,66 & \\
\hline Braki oceny & $\begin{array}{c}130 \\
(7,5 \%)\end{array}$ & $\begin{array}{c}139 \\
(8,0 \%)\end{array}$ & $\begin{array}{c}271 \\
(15,6 \%)\end{array}$ & $\begin{array}{c}282 \\
(16,2 \%)\end{array}$ & $\begin{array}{c}311 \\
(17,9 \%)\end{array}$ & $\begin{array}{c}499 \\
(28,8 \%)\end{array}$ & $\begin{array}{c}251 \\
(14,5 \%)\end{array}$ & $\begin{array}{c}700 \\
(40,4 \%)\end{array}$ & \\
\hline
\end{tabular}

Źródło: opracowanie własne na podstawie danych PGSW 2015. Dane ważone. Elektoraty z wyborów parlamentarnych w 2015 roku. Partie oceniane są przez respondentów na skali od 0 (,zdecydowanie się nie podoba”) do 10 (,zdecydowanie się podoba”).

Tabela 2 przedstawia oceny partii przez poszczególne elektoraty, czyli pokazuje, które elektoraty doceniają również inne partie, poza ich własną, a jakie „okopały się” w nieufności do pozostałych. Różnice między „własną” partią a pozostałymi są duże we wszystkich elektoratach, jednak najwyższy poziom sympatii do własnej partii wykazywany jest przez elektorat PiS (7,69 punktu), a najmniej lubią własną partię zwolennicy PSL $(5,81)$. Najbardziej nie lubią innych partii wyborcy PiS - średnia dla innych partii wynosi niecałe 2,29; przekłada się to również na drugą największą różnicę między sympatią do własnej partii a stosunkiem do innych $(5,4)$ - wyższa charakteryzuje jedynie wyborców KORWiN $(5,6)$. Wyborcy PiS największą niechęć czują wobec partii KORWiN 
$(1,65)$, a w dalszej kolejności - wobec partii lewicowych: koalicji ZL $(1,75)$ i partii Razem $(1,8)$. Na drugim biegunie znaleźli się zwolennicy Razem, których niechęć do pozostałych ugrupowań jest istotnie mniejsza (średnia 2,9). Niegłosujący stosunkowo najmniej nie lubią PiS $(4,01)$, Kukiz'15 $(3,39)$ i PO $(3,23)$.

Oceny poszczególnych partii są ze sobą $\mathrm{w}$ większości skorelowane w sposób istotny statystycznie, czyli pozytywna ocena danej partii będzie się wiązała z pozytywną lub negatywną oceną innej (patrz wykres 2). Najsilniejszy negatywny związek występuje między ocenami PiS i PO ( $\mathrm{r}$ Pearsona $=-0,34)$. Poza Platformą sympatykom PiS nie podoba się Nowoczesna $(-0,26)$, Zjednoczona Lewica $(-0,22)$ i, w mniejszym stopniu, Razem $(-0,09)$ i PSL $(-0,05)$, a podoba Kukiz'15 $(0,30)$ i, znacznie mniej, KORWiN $(0,11)$. Przeciwny kierunek zależności występuje pomiędzy ocenami wszystkich partii a PO, z sympatią do której silnie powiązana jest pozytywna ocena PSL $(0,44)$, Nowoczesnej $(0,42)$ i Zjednoczonej Lewicy $(0,4)$, a także Razem $(0,26)$ i negatywna ocena Kukiz'15 $(-0,14)$ i KORWiN $(-0,10)$. Między parami pozostałych partii zdecydowanie dominują korelacje pozytywne: sympatie wobec PSL, ZL, .N i Razem są negatywnie skorelowane wyłącznie ze stosunkiem do PiS, a oceny Kukiz'15 i KORWiN - jedynie ze stosunkiem do PO.

Spośród wszystkich respondentów $73 \%$ oceniło jedną z partii, o które pytaliśmy, jednoznacznie najwyżej ze wszystkich (niezależnie jak wysoka ocena to była), a pozostałe osoby przyznały najwyższą ocenę więcej niż jednej partii lub nie oceniły żadnej partii). Jak przedstawia to tabela 3, najwięcej tak zdefiniowanych jednoznacznych zwolenników ma Prawo i Sprawiedliwość - aż 41,5\% wszystkich osób, które posiadają partię, którą oceniają lepiej niż inne, wskazało na to ugrupowanie. Następne w kolejności były Platforma Obywatelska (15,6\% wskazań) i Nowoczesna (14,7\%). Najmniej osób wskazało jako ulubione ugrupowania lewicowe - koalicję ZL (4,4\%) i partię Razem (3,8\%). 


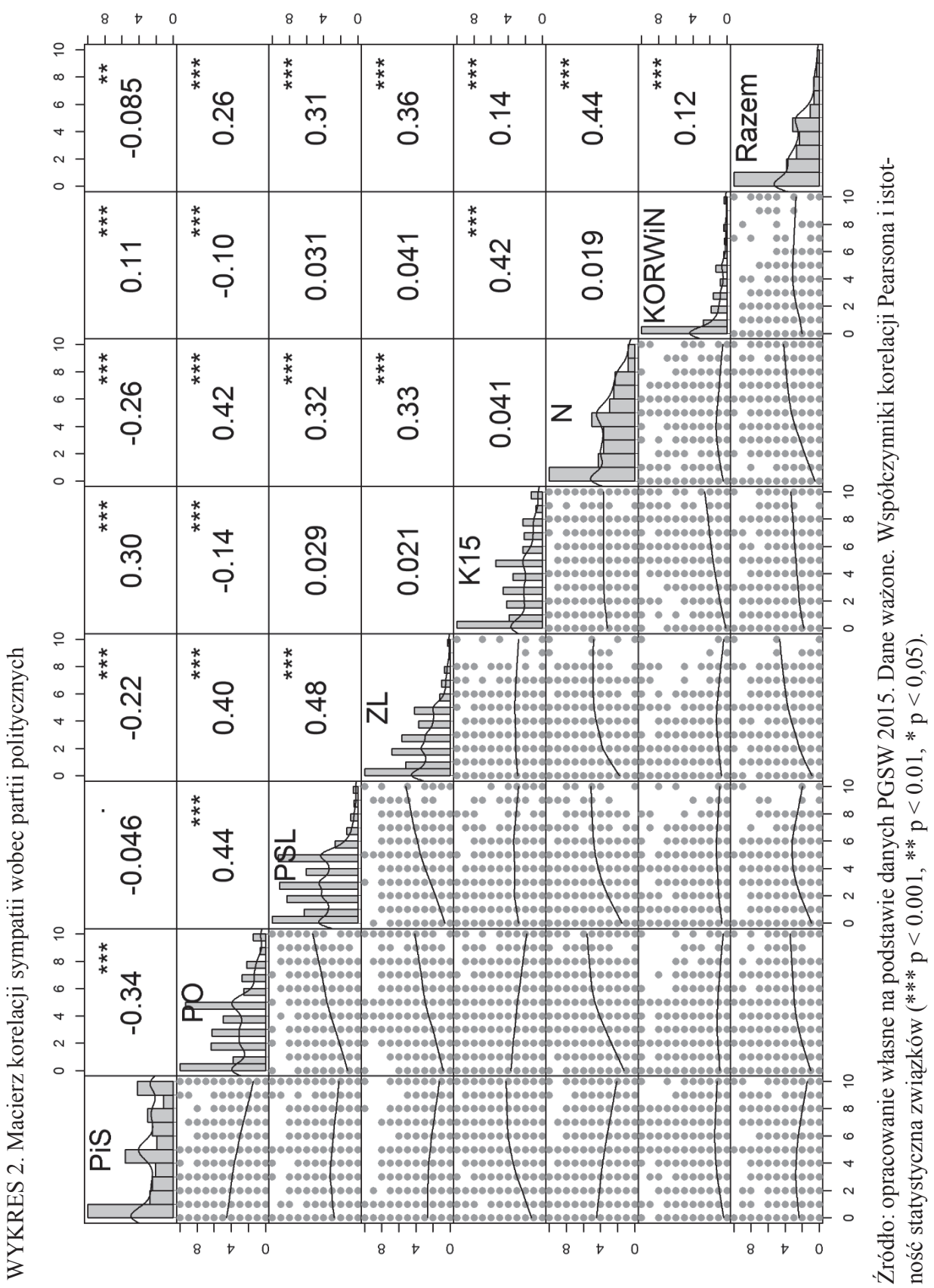


TABELA 3. Sympatie partyjne a zachowania wyborcze

\begin{tabular}{|c|c|c|c|c|c|c|c|c|c|c|c|}
\hline & \multirow{2}{*}{$\frac{\mathrm{N}}{\text { w próbie }}$} & \multirow{2}{*}{$\begin{array}{c}\text { \% w pró- } \\
\text { bie }\end{array}$} & \multicolumn{8}{|c|}{ Głosowanie w wyborach parlamentarnych 2015 (w \%) } \\
\hline & & & & PiS & $\mathrm{PO}$ & PSL & ZL & K'15 &. $\mathrm{N}$ & $\begin{array}{l}\text { KOR- } \\
\text { WiN }\end{array}$ & $\mathrm{R}$ \\
\hline \multirow{8}{*}{$\begin{array}{l}\text { Jednoznaczni } \\
\text { sympatycy }\end{array}$} & PiS & 525 & 30,3 & 95,1 & 2,5 & 1,1 & 0,3 & 0,8 & & & 0,3 \\
\hline & $\mathrm{PO}$ & 198 & 11,4 & 5,9 & 92,6 & & & & 1,5 & & \\
\hline & PSL & 54 & 3,1 & 9,7 & 12,9 & 71,0 & 3,2 & 3,2 & & & \\
\hline & ZL & 42 & 2,4 & 7,7 & 7,7 & 3,8 & 65,4 & 3,8 & 7,7 & & 3,8 \\
\hline & $\mathrm{K}^{\prime} 15$ & 141 & 8,1 & 12,3 & 4,9 & & & 81,5 & & 1,2 & \\
\hline &. $\mathrm{N}$ & 186 & 10,7 & 4,3 & 26,6 & 3,6 & 6,5 & 1,4 & 55,4 & 0,7 & 1,4 \\
\hline & $\begin{array}{l}\text { KOR- } \\
\text { WiN }\end{array}$ & 71 & 4,1 & 23,3 & 4,7 & & & 2,3 & & 69,8 & \\
\hline & $\mathrm{R}$ & 48 & 2,8 & 5,3 & 15,8 & 2,6 & 13,2 & & 7,9 & 2,6 & 52,6 \\
\hline
\end{tabular}

Źródło: opracowanie własne na podstawie danych PGSW 2015. Dane ważone. Niegłosujący i osoby bez jednoznacznie najlepiej ocenianej jednej partii jako braki danych.

Spośród osób, które oceniły jedną partię lepiej niż inne, nie wszystkie na nią zagłosowały. W przypadku dwóch największych ugrupowań (PiS i PO) sympatie partyjne przekładają się niemal w pełni na decyzje wyborcze (powyżej 90\%). PSL i ZL, na które głosowało odpowiednio 71\% i 65\% jednoznacznych sympatyków, straciły ich głównie na rzecz PO i PiS, ZL również na korzyść Nowoczesnej. Spośród nowych partii najwyższy odsetek tak rozumianych sympatyków zachowały blok Kukiz'15 (82\%) oraz KORWiN (70\%) - w obu przypadkach największa grupa spośród wyborców, którym partia podoba się najbardziej, ale na nią nie zagłosowali, zdecydowała się poprzeć PiS. Najsilniej głosowanie strategiczne widoczne było w przypadku Nowoczesnej (która zachowała 55\% sympatyków) i Razem (53\%) - co ciekawe, niezależnie od bardzo zróżnicowanych programów ideologicznych tych ugrupowań w obu przypadkach największe grupy wyborców odeszły do PO, a w dalszej kolejności do Zjednoczonej Lewicy.

Zgodnie z danymi PGSW niechęć do partii konkurencyjnej nie jest dla wyborców decydującą determinantą decyzji wyborczej. Przedstawione w tabeli 4 modele regresji logistycznej przedstawiają wpływ sympatii i antypatii do różnych partii politycznych na głosowanie na poszczególne ugrupowania. W przypadku niektórych elektoratów istotny statystycznie jest głównie stosunek do partii, na którą zdecydowali się głosować. Dla innych grup wyborców ich decyzja przy urnie jest determinowana stosunkiem do wielu ugrupowań. 
TABELA 4. Wpływ sympatii partyjnych na decyzje wyborcze

\begin{tabular}{|c|c|c|c|c|c|c|c|c|}
\hline \multirow{3}{*}{$\begin{array}{l}\text { Stosunek } \\
\text { do partii: } \\
0 \text { - nie podoba } \\
\quad \text { się, } \\
10 \text { - podoba się }\end{array}$} & \multicolumn{7}{|c|}{ Głosowanie w wyborach parlamentarnych 2015 roku } & \multirow{2}{*}{$\begin{array}{l}\begin{array}{l}\text { LR chi }^{2} \\
\text { (Sig.) }\end{array} \\
\text { Pełny } \\
\text { model: }\end{array}$} \\
\hline & PiS & PO & PSL & ZL & K'15 &. $\mathrm{N}$ & $\begin{array}{l}\text { KOR- } \\
\text { WiN }\end{array}$ & \\
\hline & $\operatorname{Exp(B)}$ & $\operatorname{Exp(B)}$ & $\operatorname{Exp(B)}$ & $\operatorname{Exp}(B)$ & $\operatorname{Exp}(B)$ & $\operatorname{Exp}(B)$ & $\operatorname{Exp}(B)$ & $1655,4 * * *$ \\
\hline PiS & $1,72 * * *$ & $0,82 * * *$ & $0,72 * *$ & $0,82 *$ & $0,85^{* *}$ & $0,79 * *$ & 0,90 & $406,2 * * *$ \\
\hline $\mathrm{PO}$ & 0,96 & $1,73^{* * *}$ & $0,74 *$ & $0,59 * * *$ & $0,84^{*}$ & 0,91 & 0,95 & $181,1 * * *$ \\
\hline PSL & 0,92 & 0,97 & $2,21 * * *$ & 0,79 & 1,06 & 0,89 & 0,96 & $75,1 * * *$ \\
\hline ZL & 0,94 & 0,88 & 0,82 & $2,72 * * *$ & 0,69 *** & $0,79 *$ & $0,64 * *$ & $159,6 * * *$ \\
\hline K'15 & 1,08 & $0,83^{* *}$ & 0,97 & $0,79 *$ & 2,10 *** & $0,82 * *$ & 1,19 & $196,4 * * *$ \\
\hline. $\mathrm{N}$ & 0,92 & $1,16^{* *}$ & 1,03 & $1,43^{* * *}$ & 1,04 & $2,35 * * *$ & 1,11 & $189,2 * * *$ \\
\hline KORWiN & $0,86 * *$ & $0,79 * *$ & 0,81 & $0,68^{*}$ & $0,86^{*}$ & \begin{tabular}{l|l}
0,90 \\
\end{tabular} & $1,97 * * *$ & $120,5 * * *$ \\
\hline $\begin{array}{l}\text { \% poprawnych } \\
\text { przewidywań }\end{array}$ & $79,6 \%$ & $62,6 \%$ & $23,1 \%$ & $59,4 \%$ & $44,6 \%$ & $56,8 \%$ & $65,1 \%$ & \\
\hline
\end{tabular}

Źródło: opracowanie własne na podstawie danych PGSW 2015. Dane ważone. $\mathrm{N}=1071$. Regresja wielomianowa logistyczna: podane ilorazy szans $(\operatorname{Exp}(B))$ i istotność statystyczna $\left({ }^{*} \mathrm{p}<0.05\right.$, $* * \mathrm{p}<0,01, * * * \mathrm{p}<0,001)$. Niegłosujący jako grupa referencyjna. Ze względu na dużą liczbę braków danych model nie obejmuje partii Razem. Odsetek poprawnych przewidywań (uwzględniając niegłosujących): 63,2\%, Nagelkerke Pseudo $\mathrm{R}^{2}=0,813$.

Dla poszczególnych grup wyborców stosunek do partii, na którą głosują, ma różny wpływ na decyzję wyborczą. Największe znaczenie ma on w przypadku wyborców Zjednoczonej Lewicy: przy innych czynnikach utrzymywanych na stałym poziomie wzrost oceny tej koalicji o jeden punkt na skali powoduje ponad dwukrotny wzrost szans zagłosowania na partię (iloraz szans wynosi 2,72). Nieco mniejszy wpływ sympatii wobec własnej partii na decyzję wyborczą występuje w przypadku Nowoczesnej $(2,35)$, PSL $(2,21)$ i Kukiz' $15(2,10)$, a najsłabszy jest dla wyborców PiS $(1,72)$ i PO $(1,73)$. Z kolei najbardziej niezależne w swoich wyborach od stosunku do innych partii są elektoraty partii KORWiN i PiS. W przypadku dwóch pierwszych partii, poza oceną własnego ugrupowania, na decyzję wyborcząjego zwolenników w sposób istotny statystycznie wpływa stosunek (negatywny) do tylko jednego innego ugrupowania, a jeśli chodzi o PSL - dwóch: są to ZL dla wyborców KORWiN (iloraz szans równy 0,64), KORWIN dla wyborców PiS $(0,86)$ oraz PiS i PO (odpowiednio 0,72 i 0,74$)$ dla wyborców PSL. Natomiast na zachowania wyborcze elektoratów ZL, PO i Kukiz'15 wpływa stosunek do większości pozostałych ugrupowań. Dla Lewicy są to: .N, PiS, K'15, KORWiN i PO; dla Platformy: .N, K'15, PiS i KORWiN; a dla wyborców bloku Kukiz'15: KORWiN, PiS, PO oraz ZL. Jedynie w przypadku Nowoczesnej ten wpływ ma charakter dodatni we wszystkich przypadkach, gdy jest istotny statystycznie, co świadczyć może o istniejącym wówczas potencjale partii. 
Największe znaczenie dla ogółu wyborców ma stosunek do PiS $\left(\mathrm{LR} \mathrm{chi}^{2}=406\right)$ : jedynie dla wyborców KORWiN niechęć wobec Prawa i Sprawiedliwości nie jest czynnikiem wpływającym w sposób istotny na decyzję wyborczą. Najmniejsze znaczenie dla elektoratów ma stosunek wobec PSL $\left(\right.$ LR chi $\left.^{2}=75\right)$ - stosunek do PSL jest czynnikiem wpływającym na głosowanie tylko dla jego elektoratu.

Przewidywanie decyzji wyborczych na podstawie stosunku emocjonalnego do partii daje znacznie lepsze efekty niż przewidywanie na podstawie pozycji ideologicznych wyborców. Najskuteczniejsze przewidywania decyzji wyborczej na podstawie stosunku do partii mają miejsce w przypadku wyborców PiS (79,6\%), KORWiN (65,1\%), a najtrudniej na ich podstawie zaklasyfikować poprawnie elektorat PSL (23,1\%) i Kukiz'15 (44,6\%). Świadczy to o tym, że inne determinanty decyzji wyborczych, które nie przekładają się na emocje wobec partii, mają większe znaczenie.

Postawy wyborców wobec kwestii politycznych wywierają wpływ o zróżnicowanej sile nie tylko na decyzję wyborczą, ale również na samą ocenę partii. Sympatia wobec partii niewyróżniających się ideologicznie w zakresie głównych osi podziałów jest w mniejszym stopniu uwarunkowana poglądami politycznymi wyborców. W tabeli 5 przedstawiony został wpływ poglądów politycznych wyborców na ich sympatie partyjne. Liczba istotnych kwestii różni się między partiami, co możemy zinterpretować, podobnie zresztą jak w przypadku tabeli 1 (wpływ poglądów na głosowanie), jako wyznacznik stopnia ich zideologizowania.

TABELA 5. Wpływ poglądów politycznych na sympatie wobec partii politycznych

\begin{tabular}{|l|c|c|c|c|c|c|c|}
\hline & PiS & PO & PSL & ZL & K'15 & .N & KORWiN \\
\cline { 2 - 7 } & $\beta$ & $\beta$ & $\beta$ & $\beta$ & $\beta$ & $\beta$ & $\beta$ \\
\hline $\begin{array}{l}\text { państwo } \\
- \text { Kościół }\end{array}$ & $0,27 * * *$ & $-0,06$ & 0,01 & $-0,08^{* *}$ & $0,07 *$ & $-0,11^{* *}$ & 0,04 \\
\hline podatki & $-0,05$ & 0,02 & 0,01 & $-0,05$ & $-0,04$ & $0,09 * *$ & $0,07 * *$ \\
\hline $\begin{array}{l}\text { Unia } \\
\text { Europejska }\end{array}$ & $0,16^{* * *}$ & $-0,21 * * *$ & $-0,11^{* * *}$ & $-0,09 * *$ & $0,18^{* * *}$ & $-0,18^{* * *}$ & $0,15^{* * *}$ \\
\hline migranci & $0,12^{* * *}$ & $-0,08 * *$ & 0,01 & $-0,01$ & $0,07 *$ & $-0,07 *$ & $0,08^{* *}$ \\
\hline $\begin{array}{l}\text { świadczenia } \\
\text { socjalne }\end{array}$ & $-0,03$ & 0,02 & $-0,03$ & $-0,03$ & 0,04 & $0,09 * *$ & $0,19 * * *$ \\
\hline prywatyzacja & $0,13 * * *$ & $-0,05$ & 0,01 & $-0,05$ & $-0,02$ & $-0,10^{* *}$ & $-0,10^{* * *}$ \\
\hline aborcja & $0,19 * * *$ & $-0,10 * *$ & $-0,02$ & $-0,14 * * *$ & $0,08 *$ & $-0,10 * *$ & $0,10^{* *}$ \\
\hline. $\mathrm{N}$ & 1603 & 1594 & 1462 & 1451 & 1251 & 1096 & 1304 \\
\hline Skor. $\mathrm{R}^{2}$ & 0,28 & 0,10 & 0,01 & 0,06 & 0,07 & 0,14 & 0,12 \\
\hline
\end{tabular}

Źródło: opracowanie własne na podstawie danych PGSW 2015. Dane ważone. Regresja liniowa: podane współczynniki standaryzowane $(\beta)$ i istotność statystyczna $\mathrm{t}(* \mathrm{p}<0.05, * * \mathrm{p}<0,01$, $* * * \mathrm{p}<0,001)$. 
Najmniej wyróżniające się ideologicznie jest, ponownie, PSL, na stosunek do którego wpływa wyłącznie negatywna postawa wobec zacieśniania współpracy w ramach Unii Europejskiej. Po trzy kwestie w sposób istotny statystycznie determinują stosunek do PO i ZL: pozytywny stosunek wobec Unii (w przypadku PO również wobec osiedlania się cudzoziemców) oraz wobec dopuszczalności aborcji (w przypadku ZL również negatywny stosunek do wpływu Kościoła na politykę). W przypadku części ugrupowań ważne okazują się wszystkie (.N) lub niemal wszystkie kwestie (z wyłączeniem postaw wobec politycznej działalności Kościoła w przypadku KORWiN i wobec systemu podatkowego i zakresu świadczeń socjalnych w przypadku PiS). Potwierdzają to zróżnicowane miary skorygowanego $\mathrm{R}^{2}$, wskazujące na większy odsetek wyjaśnionej zmienności w przypadku partii bardziej wyrazistych ideologicznie (PiS, .N, KORWiN). Pomimo tego, że w badaniu PGSW 2015 respondenci zapytani zostali o postawy wobec tylko siedmiu kwestii, wśród których nieobecny był, między innymi, podział miasto-wieś, badania CBOS oparte na szerokim katalogu kwestii politycznych potwierdzają, że z badanych elektoratów wyborcy PSL mają najmniej wyraziste poglądy, zbliżone do średnich ogółu społeczeństwa. Z kolei najbardziej wyrazisty ideologicznie jest elektorat partii KORWiN [CBOS 2015].

Istnieją również kwestie, wobec których postawy ogółu wyborców przekładają się na pozytywną ocenę partii, ale nie na głosowanie na nią. W przypadku partii KORWiN są to podatki oraz stosunek do migrantów, a jeśli chodzi o PiS - stosunek do migrantów i do prywatyzacji. Z kolei na głosowanie na ZL nie przekładają się postawy wobec relacji państwo-Kościół, chociaż są istotnymi determinantami oceny tej koalicji przez ogół wyborców, podobnie jak stosunek do relacji z Unią w przypadku PSL, natomiast nie znajdziemy takich rozbieżnych kwestii w przypadku PO. Chociaż na stosunek ogółu społeczeństwa do Nowoczesnej wpływają wszystkie badane kwestie, to głosowanie na tę partię nie jest związane z postawami wobec kwestii światopoglądowych - aborcji i działalności politycznej Kościoła. Najbardziej intrygująco pod tym względem wygląda blok Kukiz'15: ocena tego ruchu wśród ogółu wyborców zależy od szeregu kwestii natury światopoglądowej i europejskiej (państwo-Kościół, aborcja, Unia Europejska, migranci), jednak na decyzję o głosowaniu na tę partię wpływ ma tylko jedno zagadnienie: postawy wobec zakresu państwowych świadczeń socjalnych. 


\section{POGLĄDY I SYMPATIE PARTYJNE A WIEDZA POLITYCZNA}

Analizowane w artykule zjawiska: poglądy polityczne, sympatie wobec partii oraz decyzje wyborcze, łączy szereg bezpośrednich i pośrednich zależności. Zakładamy, że poglądy polityczne polskich wyborców, w ramach których, zgodnie z przeprowadzonymi wcześniej analizami czynnikowymi [por. CBOS 2015; Żerkowska-Balas, Cześnik, Zaremba 2016], można wyodrębnić komponent społeczno-kulturowy, europejski oraz ekonomiczny, wpływają na ich postawy wobec ugrupowań, wyrażane na skali sympatii i antypatii. Jednocześnie, nawiązując do przytoczonych na wstępie koncepcji teoretycznych, głosowanie ze względu na zbieżność postaw politycznych z programami partyjnymi charakteryzuje niewielki odsetek jednostek: przede wszystkim grupę dysponującą szerokimi kompetencjami politycznymi i obywatelskimi.

Na bazie modułu o wiedzy politycznej z PGSW 2015, składającego się z pytań testujących wiedzę polityczną w szerokim zakresie - obejmującym fakty polityczne, aktorów, programy partyjne oraz reguły systemu politycznego [Delli Carpini, Keeter 1996] - skonstruowany został indeks wiedzy politycznej, zliczający poprawne odpowiedzi na zadane pytania. Na podstawie liczby punktów respondenci podzieleni zostali na dwie grupy - o niskiej (0-6 pkt) i wysokiej (7-13 pkt) wiedzy politycznej, co przełożyło się na rozbicie ich na dwie zbliżone liczebnościami podgrupy (odpowiednio 52\% i 48\%); poziom wiedzy jest jednak zróżnicowany między elektoratami [Cześnik, Kwiatkowska, Markowski 2016].

Przedstawione w tabeli 6 modele regresji liniowej pozwalają na porównanie wpływu poglądów politycznych jednostek na sympatie i antypatie wobec ugrupowań politycznych w dwóch podgrupach: o wysokiej i niskiej wiedzy politycznej. Zakładany jest większy wpływ poglądów na sympatie partyjne w grupie z wysoką wiedzą polityczną. Jako zmienne kontrolne w modelach zostały wprowadzone dodatkowo: głosowanie retrospektywne w wersji socjotropicznej [por. Markus 1988] (operacjonalizowane jako ocena zmiany sytuacji gospodarczej kraju w ciagu ostatniego roku), kluczowa dla modelu Michigan zgodność otoczenia respondenta $\mathrm{w}$ kwestiach politycznych (definiowana jako oszacowanie przez badanego liczby osób z bliskiego otoczenia, z którymi rozmawiał o polityce, popierających tę samą partię polityczna), a także kluczowe czynniki determinujące pozycję społeczno-ekonomicznąjednostki: poziom wykształcenia oraz dochodu (netto) gospodarstwa domowego. 


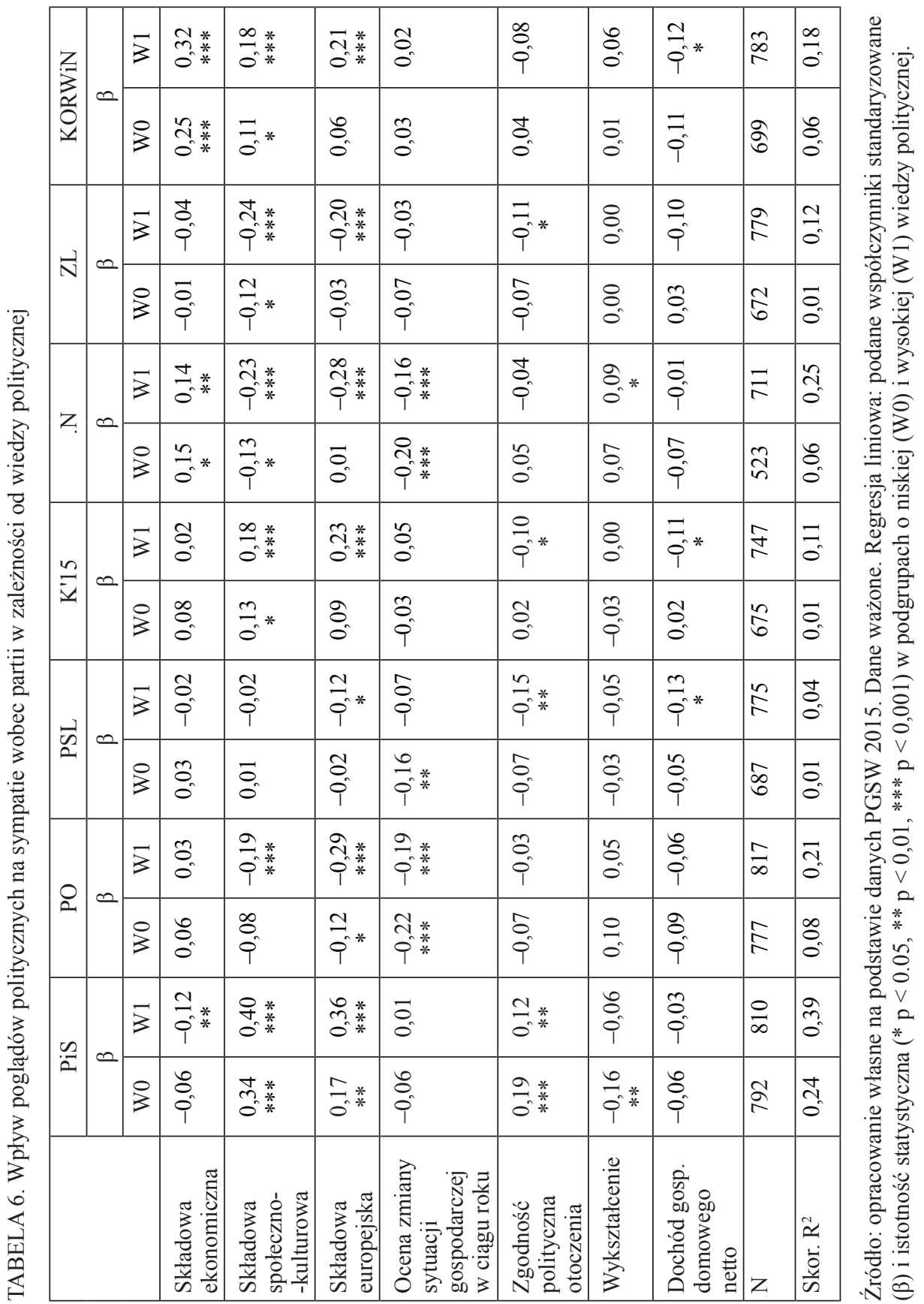


Uzyskane wyniki potwierdzają że wiedza polityczna jest zjawiskiem silnie modyfikującym kształtowanie się preferencji partyjnych ze względu na poglądy polityczne. Osoby dysponujące większymi kompetencjami politycznymi w większym stopniu kierują się swoimi preferencjami wobec kwestii szczegółowych w swoich sympatiach lub antypatiach partyjnych. Osobom mniej orientującym się w świecie polityki trudniej jest zarówno sprecyzować swoje poglądy, jak i znaleźć partię najbliższą swoim preferencjom, o czym świadczy większa liczba wskazań „nie wiem” i braków odpowiedzi na pytania dotyczące własnych poglądów, pozycji ideologicznych partii oraz sympatii i antypatii partyjnych w grupie z niskim niż w grupie z wyższym poziomem wiedzy politycznej.

Odsetek wyjaśnionej wariancji jest w przypadku oceny każdej partii wyższy w grupie osób z wysokim poziomem wiedzy politycznej. Preferencje wobec partii osób z wyższą wiedzą polityczną są w znacznie większym stopniu oparte na wyznawanych poglądach i łatwiej przewidywalne. Dotyczy to zarówno kwestii tzw. łatwych i trudnych, jednak największe różnice między grupami o różnej wiedzy dotyczą zwłaszcza składowej europejskiej i społeczno-kulturowej, w mniejszym stopniu kwestii ekonomicznych. Spośród kwestii kontrolnych charakterystyczny jest przede wszystkim wpływ oceny zmiany sytuacji gospodarczej w ostatnim roku, która okazała się ważna dla oceny partii z byłej koalicji rządzącej: PO (i wywodzącej się z niej .N) oraz PSL.

Zróżnicowane znaczenie głosowania tematycznego w obu podgrupach wyróżnionych ze względu na poziom wiedzy politycznej przekłada się na odrębne zachowania wyborcze. Osoby z wysoką wiedzą polityczną uczestniczą w wyborach w odmienny sposób niż osoby z niższą wiedzą (ANOVA F $=49,3$, $\mathrm{p}<0.000)$. W najbardziej wyraźny sposób odróżniają się od wszystkich elektoratów niegłosujący (średnia wartość indeksu wiedzy politycznej: 4,98) - podczas gdy w podgrupie z niską wiedzą polityczną nie głosowało $54,4 \%$, wśród osób z wysoką wiedzą absencja dotyczy tylko $23,8 \%$. Na przeciwległym biegunie skali znajduje się Nowoczesna (średnia: 8,9), na którą zagłosowało 8,7\% ogółu uprawnionych z grupy z wysoką wiedzą polityczną, a tylko $1,9 \%$ z niską.

Przewaga bardziej wyrafinowanych wyborców charakterystyczna jest przede wszystkim dla partii odległych ideologicznie od środka rywalizacji (Nowoczesna, Zjednoczona Lewica, Razem, KORWiN). Chociaż więc sama świadomość istnienia małych, zwłaszcza nowo powstałych, partii wymaga aktywnego zaangażowania w zdobywanie informacji o świecie polityki, to pozostałe małe, lecz znacznie bardziej rozmyte ideologicznie, partie - PSL i Kukiz'15 - przyciagnęły w większym stopniu wyborców z niższą wiedzą polityczną. Duże partie też mają wyrafinowanych wyborców, ale i sporo tzw. szumu - częsta obecność w me- 
diach, sprawia, że stają się one partiami pierwszego wyboru dla osób niezainteresowanych polityka, często w sposób niezgodny z ich poglądami. Powiększa to trudności w przewidywaniu zachowań wyborczych ogółu społeczeństwa na podstawie postaw wobec kluczowych kwestii politycznych.

WYKRES 3. Wiedza polityczna (skala 0-13): średnia wiedza z przedziałami ufności (z lewej) oraz rozkłady wiedzy politycznej (z prawej) wśród elektoratów
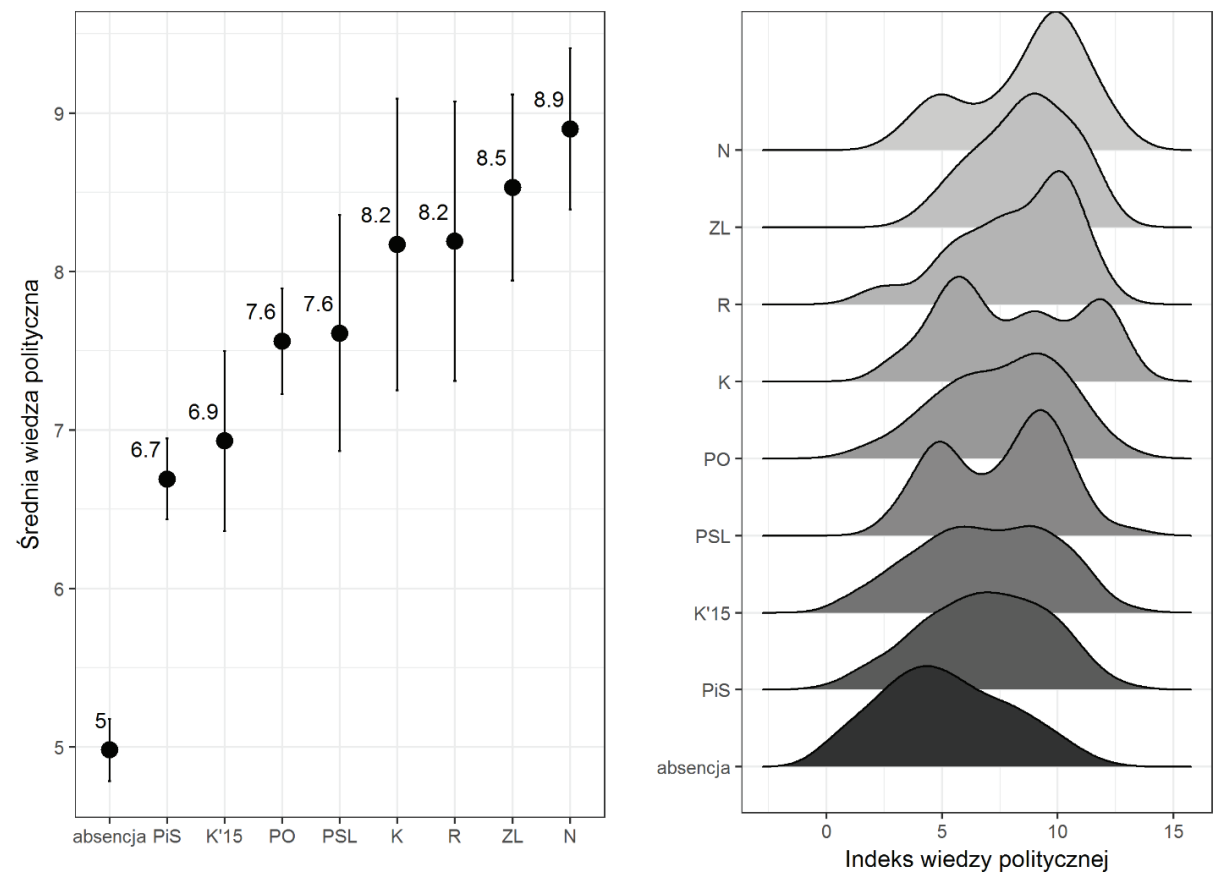

Źródło: opracowanie własne na podstawie danych PGSW 2015. Dane ważone.

\section{ZAKOŃCZENIE}

Poziom wiedzy politycznej Polaków, umożliwiającej swobodne poruszanie się po świecie polityki, w tym podejmowanie decyzji wyborczych, jest zróżnicowany między elektoratami. Duża liczba niewyrafinowanych wyborców pozwala partiom na spychanie dyskusji na tematy emocjonalne i tożsamościowe-łatwiejsze, jednak niewnoszące praktycznych rozwiązań - i unikanie rozliczenia za podjęte decyzje. Sprawia to, że partie, zamiast prezentować szerokie spektrum programów ideologicznych, skupiają się na rozbudowanym centrum (a konkretnie na społeczno-kulturowej prawicy w połączeniu z solidaryzmem ekonomicznym). 
Zawężona w ten sposób dziedzina rywalizacji sprawia, że pozycje partii są do siebie bardzo zbliżone, co ogranicza wybór obywateli. Szczególnie silnie to zjawisko jest widoczne w przypadku kwestii ekonomicznych.

Spośród badanych siedmiu kwestii najsilniejszy wpływ ogółem na zachowania wyborcze i sympatie partyjne wywierają postawy wobec Unii Europejskiej, oraz, w mniejszym stopniu, wymiar społeczno-kulturowy: postawy wobec dopuszczalności aborcji oraz wobec obecności Kościoła w polityce. Na tle wszystkich partii najbardziej wyróżniają się liberalne ekonomicznie KORWiN i Nowoczesna oraz konserwatywno-socjalny PiS. Z kolei najmniej specyficzni ideologicznie są wyborcy PSLi Kukiz'15 - w zdecydowanej większości kwestii nie różnią się od innych ugrupowań, a także charakteryzują się dużą rozbieżnością poglądów, co sprawia, że trudno mówić o ich charakterystycznych profilach programowych. Ogółem jednak same poglądy wyborców w niewielkiej mierze pozwalają na przewidywanie zarówno ich zachowań wyborczych, jak i ocen poszczególnych partii.

Pomimo tego, że elektoraty partii nie różnią się mocno poglądami, zwłaszcza w przypadku kwestii ekonomicznych, podziały polityczne na płaszczyźnie emocjonalnej są silne i stabilne i są dobrymi predyktorami decyzji wyborczych (w mniejszym stopniu dotyczy to elektoratów PSL i Kukiz'15). Polacy na ogół wyrażają silną niechęć do wszystkich partii poza tą, na którą głosują, a więcej osób jest w stanie wymienić partię, do której czuje prawdziwą niechęć niż taka, wobec której czuje, że jest im bliska lub przynajmniej bliższa niż inne. Dodatkowo, obie strony głównego podziału politycznego w Polsce próbują podważyć legitymizację drugiej strony: prawie 1/3 spośród osób, które wskazały co najmniej jedną partię, do której czują „,prawdziwą niechęć, złość”, uważa, że partia ta powinna zostać zdelegalizowana.

Słabe przełożenie poglądów wyborców na sympatie i antypatie partyjne świadczy o tym, że związek wyborców z partiami jest silnie przesunięty na płaszczyznę emocjonalną kosztem zbieżności merytorycznej. Nawiązując do koncepcji Achena i Bartelsa [2016], można określić rywalizację polityczną w Polsce jako walkę plemion, w której głosujący wybierają kandydatów partyjnych na podstawie emocji (poczucia tożsamości) w większym stopniu niż rozumu (zbieżności programów partyjnych z indywidualnymi preferencjami ideologicznymi). Przekłada się to na problemy z obiektywną oceną dokonań ugrupowań rządzących i ograniczony zasięg głosowania retrospektywnego, a tym samym na problemy z rozliczalnością rządów, i nasila dzielący Polskę konflikt polityczny - partie rywalizują ze sobą nie tyle za pomocą programów politycznych, ile przez podsycanie negatywnych emocji wśród elektoratu i budowanie na nich poczucia wspólnoty pod własnym sztandarem. 


\section{ANEKS}

\section{Treść pytań o poglądy polityczne (PGSW 2015)}

W odniesieniu do każdej kwestii politycznej istnieją różne rozwiązania. Na kolejnych skalach zaprezentujemy najbardziej skrajne stanowiska w wybranych kwestiach. Proszę je uważnie przeczytać i powiedzieć, gdzie umieścił(a)by Pan(i) swoje poglądy? Prosimy przy odpowiedzi korzystać z 7-stopniowej skali, gdzie: 1 - oznacza całkowitą zgodę z twierdzeniem, umieszczonym po lewej stronie karty, a 7 - z twierdzeniem po prawej, 4 - iż Pana(i) poglądy leżą gdzieś pośrodku obydwu twierdzeń, zaś pozostałe stopnie (punkty na skali) wyrażaja różny zakres zgody.

A. 1) Kościół powinien być od państwa całkowicie oddzielony i nie powinien zajmować się polityką

7) Kościół powinien mieć znaczny wpływ na sprawy państwa i jego politykę

B. 1) Im większy dochód ktoś uzyskuje, tym większy jego procent powinien wpłacać $\mathrm{w}$ formie podatku

7) Każdy powinien płacić w formie podatku taki sam procent od swoich dochodów

C. 1) Nasza polityka zagraniczna powinna polegać na jak najściślejszej współpracy z Unią Europejską i podporządkowaniu się regułom w niej obowiązującym

7) Nasza polityka zagraniczna powinna przede wszystkim bronić naszej politycznej i gospodarczej niezależności, nawet za cenę wystąpienia z Unii Europejskiej

D. 1) Władze powinny zachęcać do osiedlania się w Polsce obywateli innych państw, którzy mają na to ochotę

7) Władzę powinny przeciwdziałać osiedlaniu się w Polsce cudzoziemców

E. 1) Państwo powinno zapewniać obywatelom możliwie pełny zakres świadczeń społecznych (ochrona zdrowia, pomoc społeczna, kształcenie itp.) 
7) Obywatele sami powinni dbać o zapewnienie sobie ochrony zdrowia, samopomoc, kształcenie dzieci itp.

F. 1) Należy sprywatyzować wszystkie przedsiębiorstwa państwowe ...

7) Znaczna liczba przedsiębiorstw powinna pozostać własnością państwową

G. 1) Kobieta - jeśli tak zadecyduje - powinna mieć prawo do aborcji w każdej sytuacji

7) Kobieta - niezależnie od swej sytuacji społecznej czy zdrowotnej - nie powinna mieć prawa do aborcji

\section{BIBLIOGRAFIA}

Achen Christopher, Larry Bartels. 2016. Democracy for realists. Why elections do not produce responsive government. Princeton: Princeton University Press.

Bartkowski Jerzy, Mikołaj Cześnik, Michał Kotnarowski. 2011. „Determinanty głosowania w wyborach parlamentarnych 2007 r.". Studia Polityczne 27: 43-78.

Berelson Bernard R., Paul F. Lazarsfeld, William N. McPhee. 1954. Voting: A study of opinion formation in a presidential campaign. Chicago: University of Chicago Press.

Brody Richard A., Benjamin L. Page. 1972. „Comment: The assessment of policy voting”. American Political Science Review 66: 450-458.

Brug Wouter van der. 2017. Issue ownership: An ambiguous concept. W: The Sage Handbook of Electoral Behaviour: Volume 2, K. Arzheimer, J. Evans, M. Lewis-Beck (eds.), 521-537. London: Sage.

CBOS. 2011. Opinie o działalności partii politycznych. Komunikat z badań BS/140/2011. Warszawa: CBOS.

CBOS. 2015. Charakterystyka pogladów potencjalnych elektoratów partyjnych. Komunikat z badań $n r$ 85/2015. Warszawa: CBOS.

Campbell Angus, Philip E. Converse, Warren E. Miller, Donald E. Stokes. 1960. The American voter. New York: John Wiley \& Sons.

Carmines Edward G., James A. Stimson. 1980. „The two faces of issue voting”. American Political Science Review 74(1): 78-91.

Converse Philip E. 1964. The nature of belief systems in mass publics. W: Ideology and Discontent, D. E. Apter (eds.), 206-261. Glencoe: Free Press.

Cześnik Mikołaj, Agnieszka Kwiatkowska, Radosław Markowski. 2016. „Między nami ignorantami”. Polityka 3057 (27 kwietnia): 24-26.

Dahl Robert. 1995. Demokracja i jej krytycy. Kraków: Znak.

Dalton Russell J., Hans-Dieter Klingemann (eds.). 2010. Zachowania polityczne. T. 1, T. 2. Warszawa: PWN.

Delli Carpini Michael, Scott Keeter. 1996. What Americans know about politics and why it matters. New Haven: Yale University Press. 
Downs Anthony. 1957. An economic theory of democracy. New York: Harper \& Row.

Dunleavy Patrick, Ros Taylor (eds). 2017. The 2017 audit of UK democracy. http://www.democraticaudit.com/our-work/the-2017-audit-of-uk-democracy [dostęp: 30.03.2018]

Fisher Justin, Edward Fieldhouse, Mark N. Franklin, Rachel Gibson, Marta Cantijoch, Christopher Wlezien. (eds.) 2018. The Routledge handbook of elections, voting behavior and public opinion. New York: Routledge.

Fiorina Morris P. 1981. Retrospective voting in American national elections. New Haven: Yale University Press.

Kwiatkowska Agnieszka. 2018. Legislative voting unity in Central and Eastern Europe 1997 -2017. Referat wygłoszony na ECPR General Conference, Hamburg 22-25.08.2018.

Kwiatkowska Agnieszka, Mikołaj Cześnik, Marta Żerkowska-Balas, Ben Stanley. 2016. „Ideologiczna treść wymiaru lewica-prawica w Polsce w latach 1997-2015”. Studia Socjologiczne 4: 97-129.

Lewis-Beck Michael S., William G. Jacoby, Helmut Norpoth, Herbert F. Weisberg. 2008. The American voter revisited. Ann Arbor: University of Michigan Press.

Markowski Radosław, Mikołaj Cześnik, Michał Kotnarowski. 2011. Demokracja, gospodarka, polityka. Perspektywa polskiego wyborcy. Warszawa: Scholar.

Markowski Radosław, Joshua A. Tucker. 2017. „Subjective vs. objective proximity in Poland. Directions for the empirical study of political Representation”. Studia Polityczne 3(45): 9-44.

Markus Gregory B. 1988. „The impact of personal and national economic conditions on the presidential vote: A pooled cross-sectional analysis". American Journal of Political Science 32(1): 137-154.

Meer Tom W.G. van der, 2017. Political trust and the „crisis of democracy”. W: Oxford research encyclopedia of Politics, W.R. Thompson (eds.), http://politics.oxfordre.com/view/10.1093/ acrefore/9780190228637.001.0001/acrefore-9780190228637-e-77 [dostęp: 30.03.2018].

Powell Bingham G. 2004. „Political representation in comparative politics”. Annual Review of Political Science 7: 273-96.

Raciborski Jacek. 2011. Obywatelstwo w perspektywie socjologicznej. Warszawa: PWN.

Żerkowska-Balas Marta, Mikołaj Cześnik, Mateusz Zaremba. 2017. „Dynamika wiedzy politycznej Polaków". Studia Socjologiczne 3: 7-31.

Agnieszka Kwiatkowska

\section{POLITICAL PREFERENCES - PARTY EVALUATIONS - POLITICAL KNOWLEDGE. THE PREDICTION OF VOTING BEHAVIOURS IN THE 2015 POLISH PARLIAMENTARY ELECTIONS}

Summary

According to the popular perception of electoral behaviours, individuals vote for parties whose program and actions are close to their views. However, studies on voting indicate that ideological proximity is of little importance both for electoral decisions and for the evaluation of political parties, especially for people with little political knowledge. In the paper, I focus on two key determinants of electoral behaviour: attitudes towards key political issues and party evaluations, analysing the diversity of their impact due to the political knowledge of the individuals. Based on the data of the 
Polish General Election Study 2015, I show that: 1) the ideological space of political competition in Poland is limited, primarily in the area of economic issues; attitudes towards political issues are of limited importance both for voting decisions and for party evaluations; 2) despite limited ideological differences, political divisions on the emotional level are strong and are good predictors of electoral behaviours; 3 ) political knowledge is a factor that strongly affects party evaluations; people with greater political knowledge base their party evaluation on issue proximity to a greater extent.

Keywords: electoral behaviour, political preferences, political issues, issue voting, political knowledge 